\title{
POLYMORPHISMS IN GPX5 GENE AND ITS ASSOCIATION WITH PRODUCTION AND REPRODUCTION TRAITS IN NIANG MEGHA PIGS OF EASTERN HIMALAYA
}

\author{
Rakesh Kumar $^{1}$, G. Kadirvel ${ }^{1 *}$, Gautam Khargharia ${ }^{1}$, Sourabh Deori ${ }^{1}$, Sunil Doley ${ }^{1}$, Meena Das ${ }^{1}$, \\ N. Uttam Singh ${ }^{2}$, Mahak Singh $^{3}$, K. K. Baruah ${ }^{1}$, V. K. Mishra ${ }^{4}$ \\ Received 03 August 2021, revised 12 November 2021
}

\begin{abstract}
The glutathione peroxidase 5 gene (GPX5) is closely associated with the Major Histocompatibility Complex (MHC), which directly affects the reproductive traits in swine. The study was aimed to investigate polymorphism and find out associations between individual genotypes of the glutathione peroxidase 5 (GPX5) gene with reproduction and production traits in Niang Megha pigs. Genomic DNA was extracted and genotyping was performed using PCR-RFLP technique. Polymorphisms at the Intron 1 of the GPX5 gene were determined by using PCR-RFLP with HinfI restriction enzyme and DNA sequencing analyses. Two alleles and three genotypes were identified by HinfI digestion of the GPX5 gene. In the SNP-HinfI (g.1896A>G) locus did not find a significant association between GPX5 polymorphism with reproduction and production traits. However, the least square mean (LSM) values for the genotype GG demonstrated superior litter size and body weight as compared to AA and AG genotypes in the studied population. These findings emphasize the importance of the porcine GPX5 gene in the performance traits of pig. Therefore, the porcine GPX5 gene may be used as a potential candidate gene for the genetic improvement of litter size traits in the pig breeding industry.
\end{abstract}

Key words: Niang Megha Pig, GPX5, Polymorphism, Reproductive trait, Productive trait.

\section{INTRODUCTION}

The state of Meghalaya is located in a Hilly region of North-East India. Pig rearing is an essential livestock module for the tribal population of Meghalaya. Among all the livestock species (9.06 million), pig (0.71 million) plays an important role in the livelihood of the tribal people of Meghalaya, accounting for $1.69 \%$ of the total livestock population (BAHS 2019). The total pig population of the region is mainly dominated by indigenous pigs, which are locally known as "Khasi local pig" or "Niang Megha".

It can sustain under low input management conditions and easily adapt to harsh climatic conditions. Indigenous pig breeds bear unique features such as better heat tolerance, disease resistance, good maternal qualities, early sexual maturity (Karunakaran et al. 2009) and good quality bristles (Mohan et al. 2014) compared with exotic and crossbreds. The local non-descript pigs contribute 65-75 percent of the total pig population in the NorthEast region (BAHS 2019), demonstrating the importance of pig rearing for farmers' livelihood systems in the region (Zaman et al. 2015, Talukdar et al. 2019). Pork production in India is limited, accounting for only $9 \%$ of all animal protein sources in the country (Panda et al. 2018). Among the several kinds of meat, pork is the most desired meat and contributes more than $70 \%$ to the total meat consumption in this region (Kumaresan et al. 2006b). The supply-demand gap for pork is higher in the Northeast (41.02 percent) than in the rest of the country (27.40 percent), which could be due to low-input backyard production systems and a lack of elite indigenous pig breeds (Mahajan et al. 2015).

\footnotetext{
${ }^{1}$ Division of Animal and Fisheries Sciences, ICAR-Research Complex for NEH Region, Umiam-793 103, Meghalaya, India. ${ }^{2}$ Division of Technology Assessment and Capacity Building, ICAR-Research Complex for NEH Region, Umiam-793 103, Meghalaya, India.

${ }^{3}$ ICAR-Research Complex for NEH Region, Jharnapani, Medziphema-797 106, Nagaland, India.

${ }^{4}$ ICAR-Research Complex for NEH Region, Umiam-793 103, Meghalaya, India.

*Corresponding author. e-mail: velvet.2007@ rediffmail.com
} 
Polymorphisms in GPX-5 gene and its association with production and reproduction...

The reproductive traits in pig especially litter size is an utmost trait, as an increase in the number of litters per sow will increase economic returns for swine farming sector (Sato et al. 2016). The traditional selection criteria in pig breeding are laborious, expensive and mainly time consuming in the swine sector. Therefore, marker assisted selection employed to the identification of suitable markers for a reproductive trait is of great interest because these traits are sex-limited and have low heritability (Bidanel 2011). Several genes can be used as markers for reproductive traits in pig populations to use in marker assisted selection (MAS) programs (Bidanel 2011, Marantidis et al. 2013, Fang et al. 2014). The most promising candidate genes associated with reproductive traits in pigs are the oestrogen receptor gene (ESR), follicle-stimulating hormone beta subunit gene (FSHB), leptin and leptin receptor genes (LEP and LEPR), prolactin and prolactin receptor genes (PRL and PRLR), retinol binding protein 4 (RBP4), glutathione peroxidase 5 (GPX5), and several others (Onteru et al. 2009). Among them, the swine glutathione peroxidase 5 gene (GPX5) has numerous quantitative trait loci (QTL) linked to the major histocompatibility complex (MHC), which has been suggested to affect reproductive traits such as ovulation rate and litter size in swine (Buske et al. 2005). The swine GPX5 gene is of 1443 base pairs (bp) which encode a protein of 219 amino acids. It consists of 5 exons and has been mapped to swine chromosome region 7 (SSC7) (Bertani et al. 1999). To the best of our knowledge, polymorphisms in the GPX5 gene along with association studied with reproductive and productive traits were not studied in Niang Megha (NM) pig populations. Against this background, this study was aimed to evaluate the genetic polymorphisms as well as possible associations between individual genotypes with reproductive and productive traits in the GPX5 gene in Niang Megha pigs.

\section{MATERIALS AND METHODS}

\section{Geographical location and climatic description}

The animals were selected randomly from organized farmers' herd and Nucleus Pig Breeding Farm of ICAR Research complex (RC) for North Eastern Hilly (NEH) region, which is situated at $25^{\circ} 41^{\prime} \mathrm{N}$ latitude and $91^{\circ} 55^{\prime}$ E longitude with an altitude of 1010 meters above mean sea level. The region is situated in subtropical Eastern Himalayan Hilly climate and temperature rises in the summer season (May to August), ranging between $28^{\circ} \mathrm{C}$ to $29.3^{\circ} \mathrm{C}$, and experiences the highest rainfall from May to September with annual precipitation ranging from 2500 to $3000 \mathrm{~mm}$. Whereas, the winter season (November to February), is very cold with temperatures ranging from $12.3^{\circ} \mathrm{C}$ to $5.5^{\circ} \mathrm{C}$ (Chakraborty et al. 2014).

\section{Management of animals}

The experimental pigs were housed according to their sex, age and physiological condition and maintained under an intensive management system in the nucleus pig breeding farm. The pregnant sows were relocated to a farrowing pen twenty to thirty days before the estimated farrowing date. Lactating sows were fed with a standard diet (3300 ME/kg, 22.0\% crude protein). The pigs were dewormed and vaccinated regularly, and other treatments were given as required.

Majority of the farmers had housing with locally available materials such as wooden plunks or timber, bamboo sheets, and roof was made either of bricks, RCC and corrugated galvanised iron/asbestos sheet (Shadap et al. 2017). Generally, the farmers reared pigs with zero inputs like kitchen waste products as well as vegetable waste mixed with rice polish/ wheat bran, sweet potato, banana pseudo stem and colocasia. These feeds are mixed and boiled to improve digestibility and to breakdown toxins from some feeds to make the feed more palatable (Talukdar et al. 2019).

\section{Ethical approval}

The experimental plan of the study was duly permitted by the Institutional of Animal Ethics Committee (IAEC) of the ICAR Research complex (RC) for North Eastern Hilly (NEH) region, Umiam, Meghalaya, India (Approval ID and date: RC/IAEC/2020/2; 11/6/2020).

\section{Experimental animals and data collection}

Fifty-two animals were randomly selected in three successive years (2019-2021) at organized farmers' herd

Table 1. Primer sequences of the GPX5 gene in Niang Megha pig.

\begin{tabular}{lllccl}
\hline Primer set & Sequence $\left(\mathbf{5}^{\prime}-\mathbf{3}^{\prime}\right)$ & $\begin{array}{l}\text { Region } \\
\text { covered }\end{array}$ & $\begin{array}{l}\text { Amplicon } \\
\text { size }(\mathbf{b p})\end{array}$ & $\begin{array}{c}\text { Annealing } \\
\text { temperature }\left({ }^{\circ} \mathbf{C}\right)\end{array}$ & Reference \\
\hline 1. & $\begin{array}{l}\text { F-TTC ATG TAG AAC TTA TTT CTG } \\
\text { R-TGA CTT ACC CAT TCT TCA G }\end{array}$ & Intron 1 & 501 & $52.0^{\circ} \mathrm{C}$ & $\begin{array}{l}\text { Buske } \text { et al. } \\
(2006)\end{array}$ \\
\hline
\end{tabular}

*(GPX5 = Glutathione peroxidase 5; F = Forward Primer; $\mathrm{R}=$ Reverse Primer; $\mathrm{bp}=$ base pairs $)$. 
Table 2. Genetic parameters of the GPX5 gene in Niang Megha pig.

\begin{tabular}{|c|c|c|c|c|c|c|c|c|c|c|}
\hline SNP & Genotypes & $\begin{array}{l}\text { Genotypic } \\
\text { frequency }\end{array}$ & Allele & $\begin{array}{c}\text { Allelic } \\
\text { frequency }\end{array}$ & $\mathbf{N}_{\mathrm{e}}^{*}$ & $I^{*}$ & $\mathrm{Nei}^{*}$ & PIC* & $\begin{array}{c}\mathrm{X}^{2 *} \\
\text { value }\end{array}$ & $\begin{array}{l}\text { HWE } \\
\text { test* }\end{array}$ \\
\hline \multirow{3}{*}{$\begin{array}{l}\text { SNP- Hinf1 } \\
(\text { g.1896A>G) }\end{array}$} & $\mathrm{AA}(11)$ & 0.140 & A & & & & & & & \\
\hline & AG (17) & 0.469 & & 0.375 & 1.882 & 0.661 & 0.468 & 0.359 & 5.084 & $\begin{array}{l}\text { Disequi- } \\
\text { librium }\end{array}$ \\
\hline & GG (24) & 0.390 & $\mathrm{G}$ & 0.625 & & & & & & \\
\hline
\end{tabular}

$\mathbf{N}_{\mathrm{e}}^{*}$ :Effective number of alleles; I*:Shannon's information index; Nei*:Expected heterozygosity; PIC*: Polymorphism information content; $\mathbf{X}^{2 *}$ : Chi-square value; HWE*: Hardy-Weinberg dis-equilibrium.

Table 3. Least squares mean (LSMEANS) and standard errors (SE) for reproductive traits of different genotypes of GPX5 gene in Niang Megha pig.

\begin{tabular}{llllllllll}
\hline SNP & Genotypes & AP(Days) & AFC (Days) & AFF (Days) & FI (Days) & LB (No.) & LW(No.) & $\begin{array}{l}\text { LWB } \\
(\mathbf{K g})\end{array}$ & $\begin{array}{l}\text { LWW } \\
(\mathbf{K g})\end{array}$ \\
\hline SNP- & AA (11) & $220.38 \pm 2.57$ & $250.12 \pm 1.67$ & $370.02 \pm 2.41$ & $212.94 \pm 3.86$ & $5.80 \pm 0.32$ & $5.42 \pm 0.61$ & $3.49 \pm 0.37$ & $27.82 \pm 2.31$ \\
Hinf1 & AG (17) & $218.10 \pm 2.71$ & $250.16 \pm 3.11$ & $367.22 \pm 1.72$ & $216.40 \pm 2.11$ & $5.26 \pm 0.51$ & $5.21 \pm 0.27$ & $3.56 \pm 0.23$ & $28.61 \pm 1.30$ \\
(g.189 & G (24) & $220.31 \pm 1.23$ & $252.37 \pm 1.32$ & $369.54 \pm 0.81$ & $221.13 \pm 3.10$ & $6.11 \pm 0.24$ & $5.71 \pm 0.42$ & $3.49 \pm 0.17$ & $31.47 \pm 1.56$ \\
6A>G & GG & & & & & & & &
\end{tabular}

$\mathrm{AP}=\mathrm{Age}$ at puberty; $\mathrm{AFC}=\mathrm{Age}$ at first conception; $\mathrm{AFF}=\mathrm{Age}$ at first farrowing; $\mathrm{FI}=$ Farrowing intervals; $\mathrm{LB}=\mathrm{Litter}$ size at birth; LW= Litter size at weaning; LWB=Litter weight at birth; LWW =Litter weight at weaning.

Table 4. Least squares mean (LSMEANS) and standard errors (SE) for productive traits of different genotypes of GPX5 gene in Niang Megha pig.

\begin{tabular}{|c|c|c|c|c|c|c|c|c|c|}
\hline SNP & Genotypes & $\begin{array}{l}\text { BW } \\
\text { (30 d) }\end{array}$ & $\begin{array}{l}\text { BW } \\
(60 d)\end{array}$ & $\begin{array}{c}\text { BW } \\
(90 \mathrm{~d})\end{array}$ & $\begin{array}{c}\text { BW } \\
(\mathbf{1 2 0 d})\end{array}$ & $\begin{array}{c}\text { BW } \\
(150 \mathrm{~d})\end{array}$ & $\begin{array}{c}\text { BW } \\
(180 \mathrm{~d})\end{array}$ & $\begin{array}{c}\text { BW } \\
(210 \mathrm{~d})\end{array}$ & $\begin{array}{c}\text { BW } \\
(240 \mathrm{~d})\end{array}$ \\
\hline \multirow{3}{*}{$\begin{array}{l}\text { SNP- } \\
\text { Hinf1 } \\
(\text { g.1896 } \\
\text { A }>\text { G) }\end{array}$} & $\mathrm{AA}(11)$ & $3.48 \pm 0.62$ & $5.71 \pm 0.11$ & $9.52 \pm 1.47$ & $14.39 \pm 2.26$ & $20.12 \pm 1.14$ & $25.32 \pm 1.14$ & $31.14 \pm 1.02$ & $37.45 \pm 0.21$ \\
\hline & AG (17) & $3.71 \pm 0.23$ & $5.42 \pm 0.60$ & $9.30 \pm 2.14$ & $14.60 \pm 1.78$ & $19.76 \pm 2.10$ & $25.10 \pm 0.96$ & $30.58 \pm 0.72$ & $37.31 \pm 0.62$ \\
\hline & GG (24) & $4.01 \pm 0.56$ & $6.12 \pm 0.33$ & $10.68 \pm 1.20$ & $15.02 \pm 0.53$ & $20.89 \pm 1.60$ & $27.23 \pm 0.71$ & $33.22 \pm 0.10$ & $37.11 \pm 0.32$ \\
\hline
\end{tabular}

*BW: Body weight $(\mathrm{kg})$

$(n=13)$ and nucleus pig breeding farm $(n=39)$ of ICAR Research complex (RC) for North Eastern Hill (NEH) region, Umiam, Meghalaya. The data for reproductive and productive traits were taken from pedigree sheet of the animals. The reproductive traits such as age at puberty (AP), age at first conception (AFC), age at first farrowing (AFF), farrowing intervals (FI), litter size at birth (LB), litter size at weaning (LW), litter weight at birth (LWB), litter weight at weaning (LWW); and data on body weight (BW) were recorded at monthly interval from birth up to 8 months of age.

\section{Genomic DNA extraction}

Genomic DNA was isolated from blood samples using the Qiagen DNeasy Blood and tissue kit, diluted to working concentration $\left(30 n g \mathrm{Il}^{-1}\right)$ and stored at $-20^{\circ} \mathrm{C}$, which were used as templates for polymerase chain reaction (PCR) amplification.

\section{Targeted regions and $\mathrm{PCR}$ amplification}

Based on the reference sequence (AF124818.1) of the swine GPX5 gene, a reported set of PCR primer (Buske et al. 2006) was used to amplify the targeted region encompassing intron 1, of the GPX5 gene in pig population. The primer sequence, product size, amplified region, and annealing temperature are presented in 


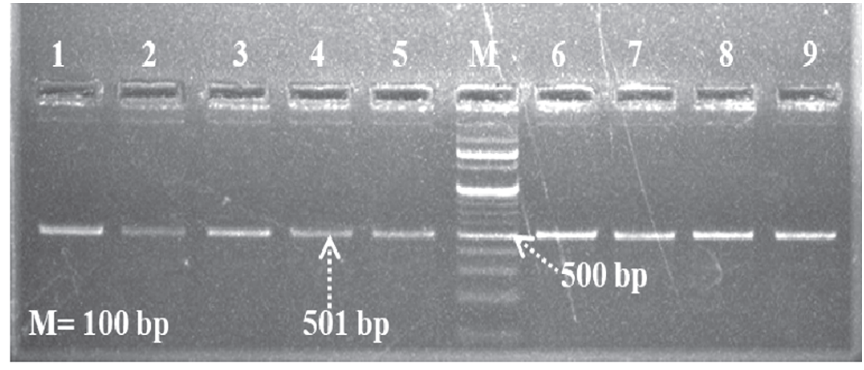

Fig. 1. PCR amplification product of the GPX5 gene in Niang Megha pig.

Table 1. PCR amplification of locus was carried out in $25 \mu \mathrm{l}$ volume with $30 \mathrm{ng} \mu^{-1}$ genomic DNA, $1.0 \mu \mathrm{M}$ of each forward and reverse primers, PCR Master Mix (2X) (Thermo Fisher) of $12.5 \mu \mathrm{l}$, and $8.5 \mu \mathrm{l}$ of water. PCR was carried out in thermal cycler (Eppendorf) in the following stages: initial denaturation at $95^{\circ} \mathrm{C}$ for $3 \mathrm{~min}$, followed by 37 cycles of denaturation at $95^{\circ} \mathrm{C}$ for $30 \mathrm{sec}$, annealing at $51^{\circ} \mathrm{C}$ for $45 \mathrm{sec}$, extension at $72^{\circ} \mathrm{C}$ for $1 \mathrm{~min}$, and a final extension at $72^{\circ} \mathrm{C}$ for $5 \mathrm{~min}$. The $\mathrm{PCR}$ products

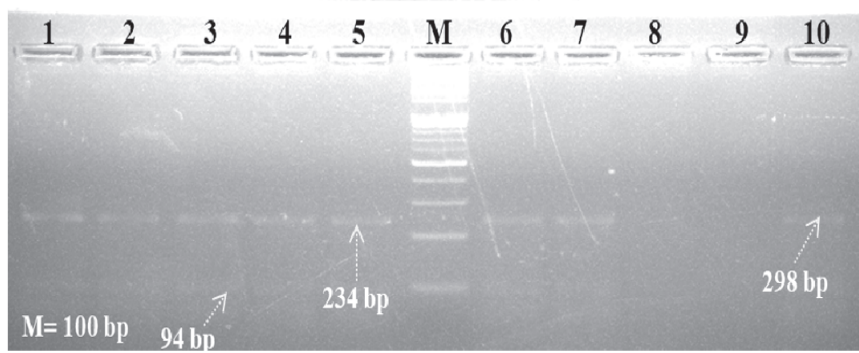

Fig. 2. Electrophoresis pattern of polymorphisms of the GPX5 gene in Niang Megha pig.

information content (PIC) were estimated by PopGene version 1.32 (Yeh et al. 1999). Associations among genotypes with reproductive traits viz. age at puberty (AP), age at first conception (AFC), age at first farrowing (AFF), farrowing intervals (FI), litter size at birth (LB), litter size at weaning (LW), litter weight at birth (LWB), litter weight at weaning (LWW); and production traits were analyzed using a general linear model (GLM) procedure of SPSS Version 16.0.

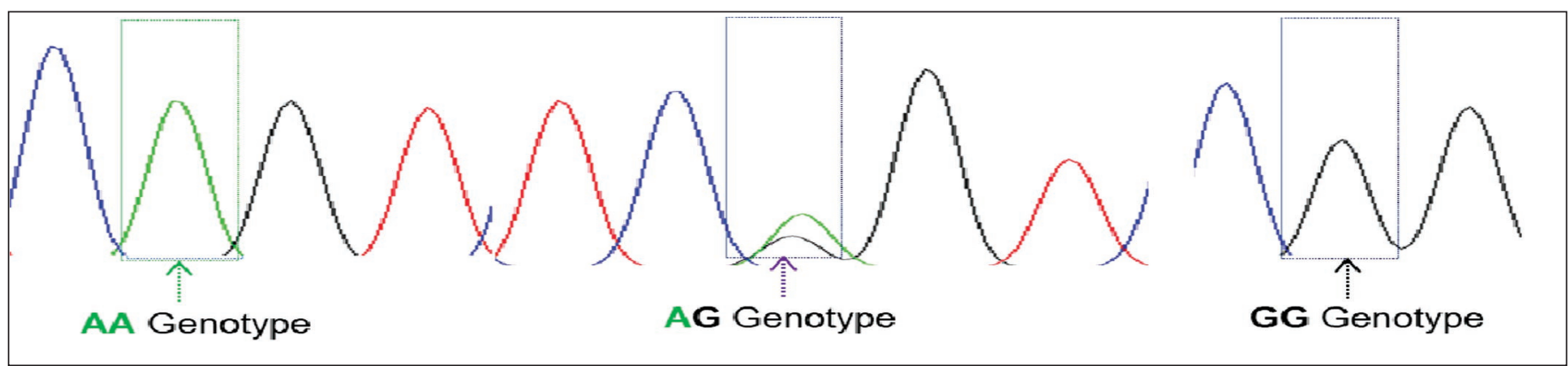

Fig. 3. Chromatogram showing polymorphism at SNP-Hinf1 locus (g.1896A>G) of GPX5 in Niang Megha pig.

were detected by electrophoresis using a $1.8 \%$ (Fig. 1) and $3.0 \%$ (Fig. 2) agarose gel in $0.5 \times \mathrm{TBE}$ (tris-borateEDTA buffer) mixed with $0.5 \mu \mathrm{g} / \mathrm{ml}$ ethidium bromide stain and was visualized under GeNei ${ }^{\text {TM }}$ Imaging System.

\section{Digestion of PCR product by RE}

The restriction digestion (RE) was carried out in $20 \mu \mathrm{l}$ of reaction mixture of each sample containing $10 \mu \mathrm{l}$ of PCR product, $9.0 \mu \mathrm{l}$ of $10 \mathrm{X}$ buffer, and $1.0 \mu \mathrm{l}$ of Hinf1 enzyme (Promega). The reaction mixture was incubated overnight at $37{ }^{\circ} \mathrm{C}$, and the digested products were separated by $3.5 \%$ agarose gel and visualized on a U.V. transilluminator. The gels were photographed using GeNei ${ }^{\text {TM }}$ Imaging System.

\section{Statistical analysis}

The population parameters (gene and genotypic frequencies, effective allele number $(\mathrm{Ne})$, Shannon index (I), expected heterozygosity (Nei), and the polymorphism
The following model was used for the analysis of the variance of each trait:

$\mathrm{Y}_{\mathrm{ij}}=\mu+\mathrm{G}_{\mathrm{i}}+\mathrm{e}_{\mathrm{ij}}$
where

$Y_{i j}=$ Adjusted value of type traits of $j^{\text {th }}$ animal to $i^{\text {th }}$ genotype

$\mu=$ Overall mean

$\mathrm{G}_{\mathrm{i}}=$ Fixed effect of $\mathrm{i}^{\text {th }}$ genotype

$\mathrm{e}_{\mathrm{ij}}=$ Random error associated with $\mathrm{Y}_{\mathrm{ij}}$ observation and supposed to be NID $\left(0, \sigma^{2} \mathrm{e}\right)$

\section{RESULTS AND DISCUSSION}

\section{GPX5 SNP identification and allele frequencies}

The selected amplified PCR products were sent for purification and custom sequencing from both ends ( $5^{\prime}$ and 3 'ends). Sequences were analysed with the chromas software (version 2.6.6), and each edited sequence was 
aligned with the corresponding reference sequence (AF124818.1) using ClustalW multiple sequence alignment program (https://www.ebi.ac.uk/Tools/msa/) to identify SNP. To detect this SNP, PCR-RFLP was carried out; one SNP locus was firstly found, namely, SNP-HinfI (g.1896A>G) (Fig. 3). The SNP-HinfI locus (g.1896A >G) was located at intron 1 and mutated from A to G, after digestion by the HinfI, which could be generated fragments with lengths of 298, 234, $94 \mathrm{bp}$ and fragments with lengths of $64,53,33$ and 23 bp were not visible on an agarose gel. This finding appeared in conformity with the earlier observation of Terman et al. (2013) in the Poland pig populations. Nomenclature of detected polymorphism was done according to Bertani et al. (1999) viz. 1B1B genotype (GG), 1B2B (AG) and 2B2B (AA). The study indicated that allele $G$ at g.1896A $>G$ locus was predominant in the Niang Megha pig population. Chisquare tests revealed that g.1896A $>$ G locus did not meet with the Hardy-Weinberg equilibrium $(p<0.01)$ in the studied population.

\section{Genetic parameter of GPX5 gene polymorphisms}

Statistical analyses showed that the frequencies of genotypes and alleles were different at SNP- HinfI in resource population (Table 2). As shown in table 2, three genotypes were found for the SNP-HinfI locus in Niang Megha Pig. Consequently, the population indices of this SNP, including Ne, I, Nei, and PIC, were analysed based on genotypic frequency numbers (Table 2). The classification of PIC value demonstrated that SNP-HinfI locus specified value of 0.359 , which indicated a moderate level of genetic diversity. The GPX5 gene in the Niang Megha pig population was observed to be away from Hardy Weinberg equilibrium and heterozygote deficiency was also observed.

\section{Association of GPX5 genetic variants with reproduction and production traits}

It is worth pointing out that the study of association has been conducted using GPX5 genotypes on the reproductive and productive traits of the Niang Megha pigs were presented in Tables 3 and 4. However, we did not find any significant effect. Hence, we can assume that the analyzed marker (SNP-HinfI) may not have any important effect on the performance traits in the studied population. Other results also revealed that the GPX5 genotypes were significantly $(\mathrm{p} \leq 0.01)$ associated with the better quality of semen in boars, although no significant correlation with litter size in sows (Mackowski et al. 2004, Buske et al. 2006). Furthermore, in Italian Large
White pigs, GPX5 gene variants had linked with a variety of functional teats (Dall'Olio et al. 2012). In contrast to our finding, Polasik et al. (2017) observed significant $(\mathrm{p} \leq 0.01)$ differences with litter size, and 1B1B sows genotype had the largest litter sizes as compare to 1B2B and 2B2B genotypes in large white $\mathrm{x}$ landrace crossbred sows.

In this study, we explored a total of one SNP locus in GPX5 i.e. SNP-HinfI (g.1896A>G) located in the Intron 1 and evidence was provided constantly to prove that intron played an important role in regulating posttranscriptional mechanism, mRNA splicing, and other modes of gene regulation although Intron did not code protein (Statello et al. 2021). So, the SNP located in the Intron could be significant for the function of protein into full play. Data analysis revealed that all genotype distributions of the SNP locus were in Hardy-Weinberg disequilibrium, which implies significant $(\mathrm{p}<0.05)$ differences in genotypic and allelic distributions within the studied population. Thus, genetic variations could be probably affected by artificial selection, because selection may significantly change the genotypic and allelic distribution of the GPX5 gene. $\mathrm{He}, \mathrm{Ne}$, and PIC were used to measure genetic variation in the population, with PIC and He having higher values indicating significant levels of genetic variation. It was an intermediate polymorphism $(0.25<\mathrm{PIC}<0.5)$ at the SNP-HinfI locus in the studied breed.

Association analysis did not find a significant effect on any reproductive and productive traits in the Niang Megha pig population. The present findings agree with Buske et al. (2006), who found no significant difference in the two extreme groups for litter size in sows. Our findings fully support the observation of Zhang et al. (2010), who reported that GPX5 variants were not significantly associated with the individual birth weight at 0 and 30 days in the $\mathrm{F} 1$ hybrid pig (wild boars $\mathrm{x}$ Large White pigs) population. Furthermore, Barranco et al. (2016) also investigated the presence of GPX5 in seminal plasma and discovered that boars with high GPX5 levels had higher farrowing rates and litter sizes than boars with low GPX5 levels. Recently, Michos et al. (2021) reported that no significant relationship of GPX5 with litter sizes but significant $(p>0.04)$ and positively correlated with farrowing rates $(6.7 \%)$ in pigs. As a result, we can conclude that the GPX5 is an ideal biological marker for analysing paternal traits (sperm quality) rather than maternal traits (litter size) in sows (Buske et al. 2005, Kmiec et al. 2007). 
Polymorphisms in GPX-5 gene and its association with production and reproduction...

\section{CONCLUSION}

Results of the present study indicated that the SNPHinfI (g.1896A>G) polymorphism is not associated with reproductive and productive traits in the Niang Megha pigs' under study. Therefore, SNP-HinfI polymorphism may not be suitable in marker assisted selection programs to improve performance traits, although in other pig populations this SNP has been applied to this purpose. This is the first report that analyses the allele frequency distribution of the SNP-HinfI polymorphism in the studied breed. Ever since the present study had formulated the results based on a relatively small sample size, therefore, further investigations are required to establish the correlation of this SNP with litter size traits in larger population and diverse commercial pig breeds.

\section{ACKNOWLEDGEMENT}

This study was supported by the All India Coordinated Research Project (AICRP) on Pig, under the Indian Council of Agricultural Research (ICAR) and the Director, ICAR Research Complex for NEH Region for providing funds and facilities to carry out this research work.

\section{REFERENCES}

BAHS (Basic Animal Husbandry Statistics) (2019) Ministry of Animal Husbandry, Dairying and Fisheries, Ministry of Agriculture, Government of India.

Barranco S, Tvarijonaviciute A, Perez-Patiho C, VicenteCarrillo A, Parrilla N et al. (2016) Glutathione peroxidase 5 is expressed by the entire pig male genital tract and once in the seminal plasma contributes to sperm survival and in vivo fertility. PLoS One 11: e0162958.

Bertani GR, Marlund S, Hu ZL, Rothschild MF (1999) Mapping of the Gltauthioneperoxidase-5 (GPX5) gene to pig chromosome 7. J Anim Sci 77: 2855-2856.

Bidanel JP (2011) Biology and genetics of reproduction. In :Rothschild MF, Ruvinsky A (eds). The Genetics of pig. 2nd edn. CABI Cambridge, MA, USA, 218-241.

Buske B, Brunsch C, Zeller K, Reinecke P, Brockmann G (2005) Analysis of properdin (BF) genotypes associated with litter size in a commercial pig cross population. J Anim Breed Genet 122: 259-263.

Buske B, Sernstein I, Reißmann M, Reinecke P, Brockmann G (2006) Analysis of association of gpx5, fut1 and esr2 genotypes with litter size in a commercial pig cross population. Arch Anim Breed 49: 259-268.
Chakraborty D, Singh RK, Saha S, Roy A, Sethy BK et al. (2014) Increase in extreme day temperature in hills of Meghalaya: its possible ecological and bio-meteorological effect. J Agrometeorol 16: 147-152.

Dall'olio S, Fontanesi L, Tognazzi L, Buttazzoni L, Gallo M et al. (2012) Association analysis between DNA markers and number of functional teats in Italian Large White Pigs. In: Veterinary science: current aspects in biology, Animal pathology, clinic and food hygiene. Springer, Berlin Heidelberg (Germany). 181-185.

Fang MX, Huang YS, Ye J, Zhang W, Li Y et al. (2014) Identification and characterization of RFRP gene in pigs and its association with reproductive traits. Genet Mol Res 13: 16611671.

Karunakaran M, Mondal M, Rajarajan K, Karmakar HD, Bhat BP et al. (2009) Early puberty in local Naga boar of India: Assessment through epididymal spermiogram and in vivo pregnancy. Anim Reprod Sci 111: 112-119.

Kmiec M, Terman A, Napiera ${ }^{3}$ F, Polasik D (2007) RFLP/ HinfI polymorphism within intron 1 of glutathione peroxidase5 (GPX5) gene in AI boars. Arch Anim Breed 50: 94-199.

Kumaresan A, Hussain J, Ahmed SK, Pathak KA, Das A et al. (2006b) Growth performance of Hampshire, Large White Yorkshire and Mizo local pigs under Mizoram field conditions. Indian J Anim Sci 76(2): 148-150.

Mackowski M, Switonski M, Mackowska J, Perz W (2004) Polymorphism of the GPX-5 gene and characteristics of boar semen. Arch Anim Breed 47 (2): 165-171.

Mahajan S, Papang JS, Datta KK (2015) Meat consumption in North East India: Pattern, opportunities and implications. J Anim Res 5(1): 37-45.

Marantidis A, Papadopoulos AI, Michailidis G, Avdi M (2013) Association of BF gene polymorphism with litter size in a commercial pig cross population. Anim Reprod Sci 141:7579.

Michos I, Maria T, Boscos CM, Tsousis G, Basioura A et al. (2021) Effect of boar sperm proteins and quality changes on field fertility. Animals 11: 1813.

Mohan NH, Debnath S, Mahapatra RK, Nayak LK, Baruah S et al. (2014) Tensile properties of hair fibres obtained from different breeds of pigs. Biosyst Eng 119: 35-43.

Onteru SK, Ross JW, Rothschild MF (2009) The role of gene discovery, QTL analyses and gene expression in reproductive traits in the pig. Soc Reprod Fertil Suppl 66: 87102. 
Panda R, Pawankar KN, Laishram M, Debbarma A(2018) The relevance of pig breeds from North Eastern India towards pork production- A Review. Int J Adv Agric Sci Tech 5(7): 124-132.

Polasik D, Terman A, Kumalska M, Chomczynska O, Urbanski P et al. (2017) Effect of the polymorphism in GPX5 gene on reproductive performance traits in Large White $\mathrm{x}$ Landrace crossbreed sows. Anim Sci Pap Rep 35(1): 97-102.

Sato S, Kikuchi T, Uemoto Y, Mikawa S, Suzuki K (2016) Effect of candidate gene polymorphisms on reproductive traits in a Large White pig population. Anim Sci J 87(12): 14551463.

Shadap FR, Saharia KK, Bora L, Debbarman C, Chakraborty A et al. (2017) Influence of pig farming in livelihood improvement of farmers in Meghalaya. Int $\mathbf{J}$ Livest Res 7(7): 261-268.

Statello L, Guo CJ, Chen LL, Huarte M (2021) Gene regulation by long non-coding RNAs and its biological functions. Nat Rev Mol Cell Biol 22: 96-118.
Talukdar P, Talukdar D, Sarma K, Saikia K (2019) Prospects and potentiality of improving pig farming in North Eastern Hill region of India: An overview. Int J Livest Res 9: $1-14$.

Terman A, Mikolajczyk K, Polasik D, Pilarczyk B, B ${ }^{1}$ kowska M et al. (2013) Association between GPX5 gene polymorphism and selenium concentration in liver and kidney of wild boars from west pomerania province, Poland. Ital J Anim Sci 12: e87.

Yeh FC, Yang R, Bozle T (1999) POPGENE version 1.31, MS Windows-based freeware for population genetic analysis. University of Alberta and Centre for International Forestry Research.

Zaman G, Shekar MC, Laskar S, Ferdoci AM, Rank DN (2015) Molecular characterization of Assam local pig. Indian J Biotechnol 14: 416-419.

Zhang DJ, Liu D, Yang GW, Fu XK, He XM (2010) Impact of the GPX5, FUT1, FSH and PRLR genes on individual weight at birth and 30 days in hybrid pig. J Appl Anim Res 38: 239243.

*Cite this article as: Rakesh Kumar, Kadirvel G, Khargharia G, Deori S, Doley S, Das M, Singh NU, Singh M, Baruah KK, Mishra VK (2021) Polymorphisms in GPX5 gene and its association with production and reproduction traits in Niang Megha pigs of eastern Himalaya. Explor Anim Med res 11(2): 145-151. DOI: 10.52635/eamr/11.2.145-151. 